\title{
The development of, and response to, an academic writing module for electrical engineers at the University of Bath
}

\author{
Miranda Armstrong \\ University of Bath, UK \\ Jackie Dannatt \\ University of Bath, UK \\ Adrian Evans \\ University of Bath, UK
}

\begin{abstract}
The academic writing module for electrical engineering students, offered at the University of Bath, is the result of collaboration between the Department of Electronic and Electrical Engineering (EEE) and the English Language Centre (ELC) and is currently designed to deliver academic writing support to undergraduate students embarking on their engineering studies at Bath. The need for the course arose from subject tutor recognition of the students' lack of awareness of the genre within which they were expected to write, suggesting that not only the subject content but also the expression of that content needed input and support. This paper presents details of the academic writing input provided by the University of Bath English Language Centre, the background to the module and ongoing development based on feedback from students, academic staff and EAP (English for Academic Purposes) tutors. Feedback indicates that the course succeeds in supporting students in their writing. The principal direction for future development lies in tailoring the course to fit the modular nature of students' degrees, addressing issues connected to language proficiency and the nature of assessment.
\end{abstract}

Keywords: STEM, academic writing, Electrical Engineering, disciplines, In-sessional 


\section{Introduction}

In 2004, engineering staff at the University of Bath identified a need to raise awareness amongst undergraduate students of the importance of writing within the discipline. This aligns with a proposal that students should be encouraged to reach an 'understanding of the expectations of the communities they are writing for' (Hyland and Hyland, 2006, p.206) and to see beyond content to develop an awareness of the target genre (Alexander et al., 2008). However, it has been acknowledged that students might be unfamiliar with writing practices in their field (Deane and O'Neill, 2011, p.7) and might not have the level of accuracy valued by both academic and professional discourse communities (Ferris, 2006, p.81). Coupled with the tertiary sector focus on enhancing student employability, these perceived needs prompted a decision by the Department of Electronic and Electrical Engineering (EEE) to provide additional writing support for both home and international students making the transition from school to university. This decision resulted in the development of a bespoke module designed and delivered by the writing developers of the university's English Language Centre (ELC) in liaison with EEE staff. This provision is now in its eighth year and has become an integral part of the first year undergraduate programme.

The 2011/12 module was evaluated in order to establish whether students' awareness of and competence in STEM writing was being enhanced as a result of the classes. This article presents the findings of this evaluation. It begins with the background of the course, outlines its present form, presents student and staff responses, and concludes with implications for future writing development input.

\section{Background}

The Department of Electronic and Electrical Engineering (EEE) has incorporated material on academic English within its degree programmes since 2004. The motivation for doing so was the growing concern among the Department's academic staff that the undergraduates were increasingly less well-prepared for the academic writing and presentation tasks of their degree programmes. A number of initiatives were introduced to address the problem, including the introduction of formal technical reports in the first and second years and the development of a new first year module, 'Academic English for 
Electrical Engineering', with the ELC. The aim of this module was to provide a bespoke writing course in addition to the ELC's general In-sessional English Programme.

The Academic English module was introduced in the 2004/05 academic year as a sixcredit (100 study hours) optional module, running in semester one of the first year of the degree programmes. Students were assessed in the first week of the semester and were directed towards the unit according to their assessment result. Students were required or advised to take the module, or were directed to other optional subject modules. The academic English module continued in this form for three years until 2007/08 when syllabus changes resulted in some elements of the six-credit module being incorporated into a first year module: Electronic Laboratory Techniques. This module was a core unit for all degree programmes.

In the 2010/11 academic year, a number of changes happened. The first of these was the need to include material on Professional Engineering Practice in the earlier years of the degree programmes, resulting in increased pressure on syllabus space. The second was the start of a joint degree programme with North China Electrical Power University (NCEPU), a Chinese university with campuses in Beijing and Baoding. This resulted in approximately 20-30 students per annum directly entering the second year of selected degree programmes in EEE. The result of these changes was that EEE was unable to retain the academic English input within the core year one module and, in addition, it wanted to make the input available to both the first year students and the direct entrant second years. These desires were accommodated by the creation of a three-credit (50 study hours) optional module of academic English for electrical engineers and this is the current form of the input. In 2011/12, students were not assessed but self-selected following a presentation about the Academic English for Electrical Engineering module in induction week.

\section{The Academic English for Electrical Engineering module}

The aims of the module were to address deficiencies identified by subject tutors, principally weaknesses in the structure, layout and style of laboratory and technical reports, and to improve referencing skills, grammatical accuracy and clarity of expression [see Appendix 1 for course syllabus]. 
The course in 2011/12 consisted of eight two-hour classes, offered to the entire cohort of 125 first-year undergraduate students and 21 second-year NCEPU students; 76 attended, $19(25 \%)$ of whom were NCEPU students.

In previous years, class groupings were made largely on writing competency and whether English was the students' first (L1) or additional (L2) language. This was in anticipation of the fact that $L 1$ and $L 2$ writers might have conflicting needs. In 2011/12, the rationale for the groupings was changed, in response to the request of subject tutors, who wanted to promote integration of home and international students by mixing native and non-native writers within classes. Course content covered not only academic writing but also presentation skills, although the latter were not assessed. Formative feedback throughout the course and final assessment addressed overall report structure, referencing and academic style.

\section{Feedback and analysis}

Feedback on the module from engineering subject staff, EAP writing tutors and students has been very positive from the outset. There is consensus that the module has its place alongside the engineering input.

\section{Feedback from subject staff}

Feedback was collected from engineering subject staff involved in the assessment of the technical reports and final year project dissertations from the second and final years of the EEE degree programmes. The feedback was initially collected on an ad hoc basis and by a more formal focus group in 2011/12. The overall view was that the standard of writing had improved since the Academic English module was introduced, a typical response being 'there has definitely been less concern about the quality of the academic writing since the unit started than there was before'. Tutors also commented that 'the benefit of the sections and exercises on referencing, summarising etc. does appear to be showing in the technical reports the students subsequently produce'. The current arrangement, whereby students self-select for the course was also positively received by engineering staff, as it is much easier to administer and provides access to the discipline-specific academic writing course without adding to the increasing pressure on syllabus space. 


\section{Feedback from EAP writing tutors}

Pedagogical issues were raised at tutors' meetings throughout the eight weeks of the module. In line with subject tutors' feedback, EAP tutors reported successful outcomes, but also commented on course content, class composition and assessment.

Tutors agreed that the closer liaison established with the subject tutors had greatly benefited the content and materials used in the module, ensuring that the classes delivered what was needed. However, as engineering degrees tend to be modular in form and writing tasks can vary across modules, it was recognised that there was a risk of addressing only those writing tasks set in the first year modules. Indeed, 2011/12 course students expressed surprise that the support would not continue throughout their degree course, as a real need was perceived. The writing tutors also believed that this course could easily be extended to 10 weeks with real added value for the students.

The writing developers were confident that both native and non-native English speakers benefited from the syllabus as set. However, the different levels of language ability of the students meant that the tutors were challenged to meet the different needs of these two groups in mixed classes. There was a need for increased English language support for the non-native students, while native speaker students needed little help with accuracy, but clearly benefitted from the input on style and appropriateness. It was also found that those students with a lower level of language ability chose not to take the module for credits and so did not do the assessments, thus losing the opportunity for further feedback. This reaction to the assessment was a disappointment to the writing tutors who believed that a key benefit for the students on a course of this length was the opportunity to practise and to get feedback on writing. Indeed, it was the EAP tutors' experience that assessment tended to inhibit the rationale of the course, which was to take a formative rather than summative approach in the development of students' writing.

\section{Feedback from students}

Current and previous students were asked to fill in questionnaires [Appendix 2] that asked for their comments on their confidence in writing before and after the module, the usefulness of the different components of the module, their improvement as a result of the module, and whether they wanted further support. A total of 37 students returned questionnaires, 31 from the current cohort and six $3^{\text {rd }}$ year students who had taken the unit 
in previous years, having reflected on the extent to which the module had met their subsequent writing needs. Approximately 2/3 were non-native speakers. Feedback from students commented on content, delivery and perceived gain from attending the module.

Report structure was clearly seen as the most useful component of the course by all students, and the component most successfully mastered, and very few current students wanted more input on this. Nevertheless, previous students indicated that extra input on report structure would be as beneficial as extra input on the other components of the course. Student attitudes to their mastery of referencing were far less uniform: current $1^{\text {st }}$ years generally felt they had mastered referencing, current $2^{\text {nd }}$ years were not quite so confident and previous year students saw referencing as the aspect over which they had the least control. This could suggest that once students have to start including citation in their writing, generally later in their degree course, they find it more challenging than they had anticipated. In terms of academic language and style, 27 of the 31 current students, including four of the seven native speakers, felt that language, and not just skills, was important. All of the previous students believed that language was important, perhaps reflecting a growing realisation of the challenge to produce clear, accurate writing.

Students' feedback on the open questions asking for general comments and ideas on future support, further highlighted the perceived importance of language. Other points raised were problems with scheduling, the wish for more writing practice in class, and a comment from one previous student that much of the course content repeated work done at school. In addition, over $90 \%$ of the students expressed an interest in further academic writing support. 1:1 tutorials were clearly the preferred form for current students, while previous students were slightly more interested in weekly drop-in sessions. There were suggestions that this support continue beyond the $1^{\text {st }}$ year, and be timed to help students with particular assignments, for example final year projects.

\section{Conclusions}

The academic English course has delivered on its main aim of improving students' academic writing and the Department of Electronic and Electrical Engineering is committed to continuing this EAP provision for its students. Analysis of students' responses has proved beneficial to course development, and tracking of the current cohort will continue in 
order to inform the content and increase the effectiveness of the course in line with the students' needs.

The findings of this study might be useful to those providing writing support in the wider STEM community. Subject staff tutors, EAP writing developers and students at the University of Bath are unanimous in their recognition of the success of this module, which has become a springboard for a programme of university-wide academic writing support for all $1^{\text {st }}$ year undergraduates. Not only did the classes help students gain ability and confidence in their writing, but they also highlighted the requirements of their academic community and the gap they each needed to bridge to become effective writers in their field, which might include language as well as awareness of genre. This gap, which can become more apparent to students as their degree progresses, will vary according to the particular demands of the module. Therefore, there may be a case for writing support to also follow the subject modular pattern. By mapping provision in this way, the students will be better supported at each stage of their degree. For this continuing support to be truly effective, a commitment from both the subject and writing tutors to collaborate in the development of the module is vital. For the University of Bath tutors involved in the module, the key issues to be addressed in future development are the questions of whether native and non-native speakers should be grouped together for writing development, and the nature and purpose of assessment.

\section{References}

Alexander, O., Argent, S. and Spencer, J. (2008) EAP Essentials: a teacher's guide to principles and practice. Reading: Garnet Publishing Ltd.

Deane, M. and O'Neill, P. (2011) Writing in the Disciplines. Basingstoke, UK: Palgrave Macmillan.

Ferris, D.R., (2006) 'Does error feedback help student writers? New evidence on the shortand long-term effects of written error correction', in Hyland, K. and Hyland, F. (eds.) Feedback in second language writing: contexts and issues. New York: Cambridge University Press, pp. 81-104. 
Hyland, K. and Hyland, F. (2006) 'Contexts and issues in feedback on L2 writing: an introduction', in Hyland, K. and Hyland, F. (eds.) Feedback in second language writing: contexts and issues. New York: Cambridge University Press, pp. 1-19.

\section{Author details}

Miranda Armstrong is Course Director for the In-sessional Programme at the University of Bath English Language Centre. She is currently developing a university-wide programme for writing in the disciplines.

Jackie Dannatt has taught EAP and has co-ordinated the Academic English for Electrical Engineering course at the University of Bath. She now teaches at the University of Bristol, where she continues to focus on academic skills in the disciplines, at foundation, undergraduate and postgraduate level.

Adrian Evans is a Senior Lecturer in the Department of Electronic and Electrical Engineering at the University of Bath. He has 18 years experience of teaching technology and engineering subjects at higher education institutes in the United Kingdom and overseas and is currently the Department's Director of Undergraduate Studies. 


\section{Appendix 1}

\section{Academic English for Engineering Overview of course}

The course is delivered by the English Language Centre and looks at the structure and language of technical reports and oral presentations.

\section{Aims of the course are to be fully aware of:}

- the order and content of each section of a laboratory report

- the correct method of referencing information

- the correct method of labelling figures and tables

- how to structure and deliver a presentation

- appropriate academic style and vocabulary

\section{Assessment}

Formative assessment tasks and feedback will be given throughout the course.

\section{Week 1}

Students will study the stages of a technical report with regard to content and appropriate language. Students will also receive an introduction to oral presentations.

\section{Week 2}

Students will look at examples of abstracts and introductions for content, layout and style. Examples will be discussed.

\section{Week 3}

Students will study how to structure the description of the Investigation section of a report, with appropriate academic style and punctuation.

\section{Week 4}

Students will study examples of theory sections with academic referencing. Guidelines for referencing and quotation will be given and examples will be worked through.

\section{Week 5}

Students will look at ways of describing data and analysing results.

\section{Week 6}

Students will learn how to structure a conclusion, and to position the remaining parts of the report, that is, the Title Page, the Contents Page, the Acknowledgements and the Appendices.

\section{Week 7}

Presentations

Students will give a ten minute presentation on an agreed subject-related topic, after which feedback will be given.

\section{Week 8}

Course Review and an opportunity to address any areas arising from the course. 


\section{Appendix 2}

\section{Academic English for Electrical Engineering Student Feedback Form (Current students)}

Please tick $(\sqrt{ })$ to indicate the information below which applies to you:

The year of your course $1^{\text {st }}(\quad) 2^{\text {nd }}(\quad)$

English is your first language $(\quad)$ English is not your first language ( )

How confident did you feel in writing at the beginning of this course? ( 1 to 5 , where 5 is the most confident) $1($ ) 2( ) 3( ) $4($ ) $5($ )

How confident do you feel in writing now? (5 is the most confident) $1($ ) $2($ ) $3($ ) $4($ ) 5()

Please indicate the usefulness of the course content ( 1 to 5 , where 5 is the most positive response).

\begin{tabular}{|l|l|l|l|l|l|l|}
\hline $\begin{array}{l}\text { Report } \\
\text { structure }\end{array}$ & $\begin{array}{l}\text { Introduction } \\
\text { / Theory } \\
\text { section }\end{array}$ & $\begin{array}{l}\text { The } \\
\text { Investigation }\end{array}$ & Referencing & $\begin{array}{l}\text { Results } \\
\text { and } \\
\text { Analysis }\end{array}$ & $\begin{array}{l}\text { Abstract, } \\
\text { Conclusions, } \\
\text { and } \\
\text { Appendices }\end{array}$ & Presentations \\
\hline & & & & & \\
\hline
\end{tabular}

To what extent do you feel you have mastered this aspect of the course? ( 1 to 5 , where 5 is the most positive response).

\begin{tabular}{|l|l|l|l|l|l|l|}
\hline $\begin{array}{l}\text { Report } \\
\text { structure }\end{array}$ & $\begin{array}{l}\text { Introduction } \\
\text { / Theory } \\
\text { section }\end{array}$ & $\begin{array}{l}\text { The } \\
\text { Investigation }\end{array}$ & Referencing & $\begin{array}{l}\text { Results } \\
\text { and } \\
\text { Analysis }\end{array}$ & $\begin{array}{l}\text { Abstract, } \\
\text { Conclusions, } \\
\text { and } \\
\text { Appendices }\end{array}$ & Presentations \\
\hline & & & & & \\
\hline
\end{tabular}

Please tick $(\sqrt{ })$ any aspect you would like to see covered in more detail.

\begin{tabular}{|l|l|l|l|l|l|l|}
\hline $\begin{array}{l}\text { Report } \\
\text { structure }\end{array}$ & $\begin{array}{l}\text { Introduction } \\
\text { / Theory } \\
\text { section }\end{array}$ & $\begin{array}{l}\text { The } \\
\text { Investigation }\end{array}$ & Referencing & $\begin{array}{l}\text { Results } \\
\text { and } \\
\text { Analysis }\end{array}$ & $\begin{array}{l}\text { Abstract, } \\
\text { Conclusions, } \\
\text { and } \\
\text { Appendices }\end{array}$ & Presentations \\
\hline & & & & & \\
\hline
\end{tabular}

Is there anything else which you would like to see included in the course? 
Which writing task(s) do you feel this writing course will help? Tick any number of the following tasks or leave blank:

\begin{tabular}{|l|l|l|l|l|l|l|}
\hline Task & $\begin{array}{l}\text { Laboratory } \\
\text { report }\end{array}$ & $\begin{array}{l}\text { Technical } \\
\text { report }\end{array}$ & $\begin{array}{l}\text { Group } \\
\text { project }\end{array}$ & $\begin{array}{l}\text { Individual } \\
\text { project }\end{array}$ & $\begin{array}{l}\text { Poster } \\
\text { presentation }\end{array}$ & $\begin{array}{l}\text { Other } \\
\text { (please } \\
\text { state) }\end{array}$ \\
\hline$\sqrt{ }$ & & & & & & \\
\hline $\begin{array}{l}\text { Unit } \\
\text { code }\end{array}$ & & & & & & \\
\hline
\end{tabular}

Can you give a little detail of how exactly the course has helped you with the tasks you have indicated above:

How important is help with English language, rather than skills, during this course? (please indicate 1 to 5 , where 5 is the most positive response) $1(\mathrm{l}) 2(\mathrm{l}) 3(\mathrm{l}) 4(\mathrm{l}) 5(\mathrm{l})$

Do you have any other comments about the course in general?

If further supported was provided, in which form would prefer it to be given: Tick $(\sqrt{ })$ any of the following:

\begin{tabular}{|l|l|l|l|l|l|}
\hline Another course & Weekly drop-in sessions & & $1: 1$ tutorials & & Other (please specify) \\
\hline
\end{tabular}

Thank you.

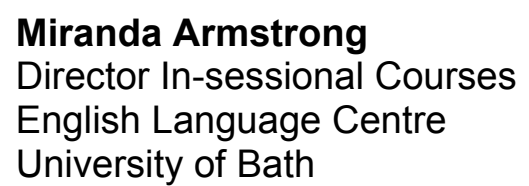

Miranda Armstrong

English Language Centre

University of Bath

Jackie Dannatt
Course Co-ordinator
English Language Centre
University of Bath

Jackie Dannatt

English Language Centre

University of Bath

\section{Dr Adrian Evans}

Director of Studies for

undergraduate degree programmes

Department of Electronic \& Electrical

Engineering

University of Bath 


\section{Informed Consent Form}

\section{What is the purpose of the questionnaire?}

You are being asked to complete a questionnaire as part of an investigation into the design of this course and its effectiveness in providing academic writing training for electrical engineering students. It is hoped that the results will be useful to both teachers and students on this course and will help to improve progress in this key skill.

\section{Data Protection}

To protect your identity and the nature of your personal responses to the tasks, your name will be removed from all materials discussed and will be replaced by a code, known only to the research team. This form will be the only document bearing your name.

AUTHORIZATION: I have read the above and understand the nature of the investigation. I grant permission to the researchers to obtain anonymous information and I understand that, by responding to the survey, I agree to allow my responses to be used in an investigation of the course provision, which may be used to inform future course design and which may be reported within the academic community to which it is of interest. I understand that if I have any concerns about the questionnaire or any other aspect of the investigation, I can contact my Department Head or the English Language Centre at any time.

Participant's signature

Date:

(If replying by email, submission will signify authorization has been given) 


\section{Academic English for Electrical Engineering Student Feedback Form (Previous students)}

Please tick $(\sqrt{ })$ to indicate the information below which applies to you:

Undergraduate ( ) Postgraduate ( )

The year of your course $1^{\text {st }}() 2^{\text {nd }}() 3^{\text {rd }}() 4^{\text {th }}() 5^{\text {th }}()$

English is your first language ( ) English is not your first language ( )

\section{PLEASE THINK BACK TO THE ACADEMIC ENGLISH SUPPORT YOU RECEIVED IN YOUR FIRST YEAR TO ANSWER THESE QUESTIONS:}

How confident in writing did you feel at the beginning of the course? ( 1 to 5 , where 5 is the most confident) $1($ ) $2($ ) $3($ ) $4($ ) $5($ )

How confident in writing did you feel at the end of the course? ( 1 to 5 , where 5 is the most confident)

$1($ ) $2($ ) $3($ ) $4($ ) $5($ )

Please indicate the usefulness of the course content ( 1 to 5 , where 5 is the most positive response).

\begin{tabular}{|l|l|l|l|l|l|l|}
\hline $\begin{array}{l}\text { Report } \\
\text { structure }\end{array}$ & $\begin{array}{l}\text { Introduction } \\
\text { / Theory } \\
\text { section }\end{array}$ & $\begin{array}{l}\text { The } \\
\text { Investigation }\end{array}$ & Referencing & $\begin{array}{l}\text { Results } \\
\text { and } \\
\text { Analysis }\end{array}$ & $\begin{array}{l}\text { Abstract, } \\
\text { Conclusions, } \\
\text { and } \\
\text { Appendices }\end{array}$ & Presentations \\
\hline & & & & & \\
\hline
\end{tabular}

To what extent do you feel you have mastered this aspect of the course? ( 1 to 5 , where 5 is the most positive response).

\begin{tabular}{|l|l|l|l|l|l|l|}
\hline $\begin{array}{l}\text { Report } \\
\text { structure }\end{array}$ & $\begin{array}{l}\text { Introduction } \\
\text { / Theory } \\
\text { section }\end{array}$ & $\begin{array}{l}\text { The } \\
\text { Investigation }\end{array}$ & Referencing & $\begin{array}{l}\text { Results } \\
\text { and } \\
\text { Analysis }\end{array}$ & $\begin{array}{l}\text { Abstract, } \\
\text { Conclusions, } \\
\text { and } \\
\text { Appendices }\end{array}$ & Presentations \\
\hline & & & & & \\
\hline
\end{tabular}

Please tick $(\sqrt{ })$ any aspect you think should have been covered in more detail.

\begin{tabular}{|l|l|l|l|l|l|l|}
\hline $\begin{array}{l}\text { Report } \\
\text { structure }\end{array}$ & $\begin{array}{l}\text { Introduction } \\
\text { / Theory } \\
\text { section }\end{array}$ & $\begin{array}{l}\text { The } \\
\text { Investigation }\end{array}$ & Referencing & $\begin{array}{l}\text { Results } \\
\text { and } \\
\text { Analysis }\end{array}$ & $\begin{array}{l}\text { Abstract, } \\
\text { Conclusions, } \\
\text { and } \\
\text { Appendices }\end{array}$ & Presentations \\
\hline & & & & & \\
\hline
\end{tabular}

Are there any other aspects you think should have been included in the course? 
Which writing task(s) do you feel this writing course helps? Tick any number of the following tasks or leave blank:

\begin{tabular}{|l|l|l|l|l|l|l|}
\hline Task & $\begin{array}{l}\text { Laboratory } \\
\text { report }\end{array}$ & $\begin{array}{l}\text { Technical } \\
\text { report }\end{array}$ & $\begin{array}{l}\text { Group } \\
\text { project }\end{array}$ & $\begin{array}{l}\text { Individual } \\
\text { project }\end{array}$ & $\begin{array}{l}\text { Poster } \\
\text { presentation }\end{array}$ & $\begin{array}{l}\text { Other } \\
\text { (please } \\
\text { state) }\end{array}$ \\
\hline$\sqrt{ }$ & & & & & & \\
\hline $\begin{array}{l}\text { Unit } \\
\text { code }\end{array}$ & & & & & & \\
\hline
\end{tabular}

Can you give a little detail of how exactly the course has helped you with the tasks you have indicated above:

How important is help with English language, rather than skills, during this course? (please indicate 1 to 5 , where 5 is the most positive response) 1() 2() 3() 4() 5()

Do you have any other comments about the course in general?

\section{NOW, PLEASE THINK ABOUT YOUR STUDIES SINCE THE $1^{\text {ST }}$ YEAR TO ANSWER THESE QUESTIONS:}

How important is academic English support beyond the $1^{\text {st }}$ year? (please indicate 1 to 5 , where 5 is the most positive response) $1($ ) $2($ ) $3($ ) $4($ ) $5($ )

If further supported was provided, in which form would you prefer it to be given: Tick $(\sqrt{ })$ any of the following:

\begin{tabular}{|l|l|l|l|l|l|}
\hline Another course & Weekly drop-in sessions & & $1: 1$ tutorials & & Other (please specify) \\
\hline
\end{tabular}

If further supported was provided, in which year of study or for which module would you like it to be?

Is there anything in particular you would like to be included?

\section{Thank you.}

Miranda Armstrong
Director In-sessional
Courses
English Language
Centre
University of Bath

Miranda Armstrong

Director In-sessiona

English Language

University of Bath

\author{
Dr Adrian Evans \\ Director of Studies for undergraduate \\ degree programmes \\ Department of Electronic \& Electrical \\ Engineering \\ University of Bath
}




\section{Informed Consent Form}

\section{What is the purpose of the questionnaire?}

You are being asked to complete a questionnaire as part of an investigation into the design of this course and its effectiveness in providing academic writing training for electrical engineering students. It is hoped that the results will be useful to both teachers and students on this course and will help to improve progress in this key skill.

\section{Data Protection}

To protect your identity and the nature of your personal responses to the tasks, your name will be removed from all materials discussed and will be replaced by a code, known only to the research team. This form will be the only document bearing your name.

AUTHORIZATION: I have read the above and understand the nature of the investigation. I grant permission to the researchers to obtain anonymous information and I understand that, by responding to the survey, I agree to allow my responses to be used in an investigation of the course provision, which may be used to inform future course design and which may be reported within the academic community to which it is of interest. I understand that if I have any concerns about the questionnaire or any other aspect of the investigation, I can contact my Department Head or the English Language Centre at any time.

\section{Participant's signature}

Date:

(If replying by email, submission will signify authorization has been given) 